Original Research Paper

\title{
Scanning Electron Microscopic Evaluation of Self- Compacting Concrete Spalling at Elevated Temperatures
}

\author{
${ }^{1}$ Mahmoud B. Alhasanat, ${ }^{1}$ Arabi N. Al Qadi, ${ }^{2}$ Omar A. Al Khashman and ${ }^{1}$ Ahmad Dahamsheh \\ ${ }^{I}$ Depatment of Civil Engineering, AlHussien Bin Tala Univ., Ma'an, Box 20, Jordan \\ ${ }^{2}$ Depatment of Environmental Engineering, AlHussien Bin Tala Univ., Ma'an, Box 20, Jordan
}

\author{
Article history \\ Received: $28-12-2015$ \\ Revised: 11-02-2016 \\ Accepted: 29-02-2016 \\ Corresponding Author: \\ Mahmoud B. Alhasanat \\ Depatment of Civil Engineering, \\ AlHussien Bin Tala Univ., Ma’an, \\ Box 20, Jordan \\ Email:20petra07@gmail.com
}

\begin{abstract}
This paper reports the effect of addition of Polypropylene (PP) fibers in the performance of Self-Compacting Concrete (SCC) under elevated temperatures. Various SCC mixtures were made with PP fiber at $0.0,0.05,0.10$ and $0.15 \%$ by volume added. The specimens were exposed to elevated temperatures $\left(200^{\circ} \mathrm{C}\left[392^{\circ} \mathrm{F}\right], 400^{\circ} \mathrm{C}\left[752^{\circ} \mathrm{F}\right]\right.$ and $600^{\circ} \mathrm{C}$ $\left.\left[1112^{\circ} \mathrm{F}\right]\right)$. The microstructure of the matrix was investigated. This study concluded that the high temperatures have a coarsening effect on the microstructure of SCC with the addition of PP fibers. It was reported that PP fibers reduced explosive spalling of SCC above $0.05 \%$ by volume and increased the number of voids in the microstructure significantly.
\end{abstract}

Keywords: Self-Compacting Concrete, Microstructure Coarsening, Elevated Temperatures, Polypropylene Fiber

\section{Introduction}

The process of investigating and collecting data related to the materials, products, structures, or components that failed is vital to the field of forensic engineering. This engrosses inspections, collecting evidence, measurements, developing models, obtaining exemplar products and performing experiments.

Fire in buildings and structures consumes lives and properties. Normal concrete is used worldwide as the main material in structures and buildings, which has led to a greater need to fully understand the effects of fire on concrete. Many researchers have investigated and documented the behavior of concrete under fire and concrete was found to have good fire resistance (Metey and Veiko, 1998). However, the behavior of SCC and HPC in fire has not yet been fully understood (Mehta and Monteiro, 1993).

The behavior of concrete at elevated temperature depends on its constituent materials, heating rate and peak temperature. Under certain heating conditions, the dehydration of C-S-H gel, the thermal incompatibility between the aggregate, cement paste and pore pressure within the cement paste are the main detrimental factors (Jahren, 1989). HPC is prone to spalling under high temperatures (Mehta and Monteiro, 1993). Concrete is found to lose its mechanical strength when subjected to severe spalling and cracking at elevated temperatures (Lea, 1920; Neves et al., 1997). Furthermore, exposure of concrete to high temperatures may also cause a change in pore structure, i.e., porestructure coarsening (Al-Mutairi and Al-Shaleh, 1997). Crook and Murray (1970) presented an experimental study on the behavior of conventional vibrated high strength concrete and self-compacting high strength concrete at high temperature with and without PP fiber. They used cylindrical and prismatic specimens at a heating rate of $0.5^{\circ} \mathrm{C} / \mathrm{min}\left(32.9^{\circ} \mathrm{F} / \mathrm{min}\right.$ ) (up to $\left.400^{\circ} \mathrm{C}\left[752^{\circ} \mathrm{F}\right]\right)$ and high heating of up to $600^{\circ} \mathrm{C}$ $\left(1112^{\circ} \mathrm{F}\right)$. They concluded that the residual mechanical properties of Self-compacting High Strength Concretes (SHSC) were similar to that of Conventional High Strength Concrete (CHSC). Spalling risk of SHSC was greater than for CHSC. The use of Polypropylene (PP) fiber improved the thermal stability of CHSC and SHSC. The addition of PP fiber modified the thermal gradient in tested concrete specimens during heating-cooling cycles.

The effect of temperature on different types of High-Strength Concrete (HSC) properties was presented (Kanéma et al., 2011). Thermal properties (specific heat, thermal conductivity and thermal expansion) are measured for these concrete types, namely, HSC, Self-Consolidating Concrete (SCC) and Fly Ash Concrete (FAC), at a temperature range from 
$20^{\circ} \mathrm{C} \quad\left(68^{\circ} \mathrm{F}\right)-800^{\circ} \mathrm{C}\left(1472^{\circ} \mathrm{F}\right)$. The fibers' (steel, polypropylene and hybrid) effect on thermal properties of HSC and SCC is also investigated. Results from their experiments showed that SCC possesses higher thermal conductivity, specific heat and thermal expansion than $\mathrm{HSC}$ and $\mathrm{FAC}$ in the $20^{\circ} \mathrm{C}\left(68^{\circ} \mathrm{F}\right)-800^{\circ} \mathrm{C}\left(1472^{\circ} \mathrm{F}\right)$ temperature range. Noumowē et al. (2006) studied the explosive spalling of concrete at elevated temperature subjected to heating-cooling cycles from room temperature to $600^{\circ} \mathrm{C}\left(1112^{\circ} \mathrm{F}\right)$. Two levels of heating rates (i.e., 0.1 and $1^{\circ} \mathrm{C} / \mathrm{min}$ ) with a fixed time of $1 \mathrm{~h}$ at the maximum temperature and a free cooling were imposed. The results showed that there was a link between the evolution of the thermal gradient in the specimens and the specimens' weight losses. Their results also showed that the thermal stability of the concrete mixes was a function of the wlc ratio, heating rate and specimen dimensions. The factors causing explosive spalling are low permeability, weak water departure from the concrete and an increase of the thermal gradient. They also concluded that the thermal gradient (i.e., thermal stress) alone could not explain the explosive spalling of concrete.

The effects of elevated temperatures up to $800^{\circ} \mathrm{C}$ $\left(1472^{\circ} \mathrm{F}\right)$ on compressive strength at different watercement ratios of SCC were studied (Kanéma et al., 2011). They found that the hot compressive strength of SCC decreases with increasing temperature. Compared with normal-strength SCC, high-strength SCC possessed a larger compressive strength when exposed to high temperature. In addition, they found that the addition of PP fibers decreased the strength and probability of explosive spalling. Peng and Huang (2008) studied the change in microstructure of hardened cement paste (hcp) at elevated temperatures using X-ray diffraction, mercury intrusion porosimetry tests and Scanning Electron Microscope (SEM) observations. The decomposition of $\mathrm{C}-\mathrm{S}-\mathrm{H}$ at $600^{\circ} \mathrm{C}\left(1112^{\circ} \mathrm{F}\right), 700^{\circ} \mathrm{C}$ $\left(1992^{\circ} \mathrm{F}\right)$ and $800^{\circ} \mathrm{C}\left(1472^{\circ} \mathrm{F}\right)$ were proposed. The C-S$\mathrm{H}$ decomposition started at $560^{\circ} \mathrm{C}$ with significant effect above $600^{\circ} \mathrm{C}\left(1112^{\circ} \mathrm{F}\right)$. This indicated that the loss of strength by concrete exposed to temperatures above $600^{\circ} \mathrm{C} \quad\left(1112^{\circ} \mathrm{F}\right)$ was related to the decomposition of HCP. They concluded that the pore size distributions confirm the coarsening effect of elevated temperatures on the pore structure, which was confirmed by the SEM analysis. The coarsening of pore structure can be regarded as the formation of equivalent cracks, which should be responsible for the reducing the HPC mechanical properties.

Nazari and Riahi (2010) investigated the microstructure, thermal properties and flexural strength of SCC with different amounts of $\mathrm{SiO}_{2}$ nanoparticles. They found that a partial replacement of cement up to
$4 \mathrm{wt} \% \mathrm{SiO}$ nanoparticle could accelerate C-S-H gel formation and increase crystalline $\mathrm{Ca}(\mathrm{OH}) 2$ amount at the early ages of hydration. They concluded that $\mathrm{SiO} 2$ nanoparticles could shift the distributed pores to harmless and improve the pore structure of concrete.

Da Silva and de Brito (2015) characterized fresh state by a decrease of the coarse aggregates and a higher volume of mortar. An experimental programme was conducted to assess the effect of incorporating Fly Ash (FA) and Limestone Filler (LF) on the concrete's porosity and the microstructure in binary and ternary mixes of SCC. The results enabled conclusions to be established regarding the SCC's durability, based on its permeability and the microstructure of its pore structure.

The main objective of this research is to investigate the microstructure of SCC with PP fibers to mitigate spalling of concrete at elevated temperatures by using scanning electron microscope. The significance of this research is to study the microstructure of concrete at elevated temperatures using a scanning electron microscope.

\section{Experimental Investigation}

\section{Materials and Mixture Proportion}

Table 1 shows plain SCC mix was designed with constituent materials. PP fiber was then added to the control mix with $0,0.05,0.10$ and $0.15 \%$ by volume of mix. Ordinary Portland Cement was used in the investigation. The specific gravity of cement was 3.15 and Blaine's fineness was $2910 \mathrm{~cm}^{2} \mathrm{~g}^{-1}$. Class F fly ash from the Kapar Thermal Power Station, Malaysia, was used as a filler. The fly ash had a specific gravity of 2.32 and Blaine's fineness of $2423 \mathrm{~cm}^{2} \mathrm{~g}^{-1}\left(28041.84 \mathrm{ft}^{2} / \mathrm{oz}\right)$. Crushed angular granite of $20 \mathrm{~mm}(0.0656 \mathrm{ft})$ maximum size was used as course aggregate. The specific gravity was 2.6, fineness modulus was 6.05 and a bulk density of $1480 \mathrm{~kg} / \mathrm{m}^{3}\left(92.40 \mathrm{Ib} / \mathrm{ft}^{3}\right)$ which conforms to an ASTM C 33-86 was used. The fine aggregates consisted of stream sand with a maximum size of $4.75 \mathrm{~mm}$ $(0.1558 \mathrm{ft})$, with normal grading, with a fineness modulus of 2-3. The absorption was $6.0 \%$ and the specific gravity was 2.5. Short PP fibers of length $19 \mathrm{~mm}$ were used in the investigation with a density of $0.91 \mathrm{~g} / \mathrm{cm}^{3}$ $\left(1.244 \mathrm{oz} / \mathrm{ft}^{3}\right)$, a melting temperature of $160^{\circ} \mathrm{C}\left(320^{\circ} \mathrm{F}\right)$, a vaporization temperature of $341^{\circ} \mathrm{C}\left(645.8^{\circ} \mathrm{F}\right)$ and a burning temperature of $460^{\circ} \mathrm{Cs}\left(860^{\circ} \mathrm{F}\right)$ given by the supplier. Poly Carboxylic Ether (PCE) based superplasticizer, which is brown in color and a free flowing liquid and has a specific gravity of 1.15 superplasticizer, according to ASTM C 494-92. Type A and Type $\mathrm{F}$ were in aqueous form to water retention and to enhance workability. Potable tap water was used for mixing and curing. 


\section{Casting and Curing}

All concrete mixes were prepared in $40 \mathrm{~L}\left(1.41 \mathrm{ft}^{3}\right)$ batches in a rotating planetary mixer. The batching sequence consisted of homogenizing the coarse aggregate and sand for $30 \mathrm{sec}$, then adding about half of the mixing water into the mixer and continuing to mix for $60 \mathrm{sec}$ more. The mixer was then covered with plastic cover to reduce the evaporation of the mixing water and to let the dry coarse aggregates in the mixer absorb the water. After $5 \mathrm{~min}$, the fly ash and cement were added and mixed for another $60 \mathrm{sec}$. Finally, the SP and the remaining water were introduced and the mixture was mixed for $3 \mathrm{~min}$. Then, the fiber was added gradually and within 2 min PP fibers were added separately and with different percentages $(0.0,0.05,0.10$ and $0.15 \%$ by volume) to the target design mix to be tested under fire. Samples of cubic $(150 \times 150 \times 150 \mathrm{~mm})(5.9 \times 5.9 \times 5.9 \mathrm{inch})$, cylinders $(150 \times 300 \mathrm{~mm})(5.9 \times 11.81$ inch $)$ and beams $(100 \times 100 \times 500 \mathrm{~mm})(3.94 \times 3.94 \times 5.9 \mathrm{ft})$ specimens were casted and cured in water at $20^{\circ} \mathrm{C}\left(68^{\circ} \mathrm{F}\right)$ for 89 days to represent the behavior of wet condition on concrete. They were then tested at 90 days to determine the mechanical properties at temperatures within the normal range, $200^{\circ} \mathrm{C}$ $\left(392^{\circ} \mathrm{F}\right), 400^{\circ} \mathrm{C}\left(752^{\circ} \mathrm{F}\right)$ and $600^{\circ} \mathrm{C}\left(1112^{\circ} \mathrm{F}\right)$.

\section{Testing at Elevated Temperatures}

The specimens were placed in an electrical box furnace of chamber size $600 \times 300 \times 300 \mathrm{~mm}$ (with a maximum temperature of $1200^{\circ} \mathrm{C}\left[2192^{\circ} \mathrm{F}\right]$ ) and a heating rate of $5-10^{\circ} \mathrm{C}\left(50^{\circ} \mathrm{F}\right)$ per minute at elevated temperature. Concrete specimens were taken out from the curing environment at 89 days and kept under dry conditions in the laboratory for one day before being exposed to fire test. The temperature was kept at $200^{\circ} \mathrm{C}$ $\left(392^{\circ} \mathrm{F}\right), 400^{\circ} \mathrm{C}\left(752^{\circ} \mathrm{F}\right)$ and $600^{\circ} \mathrm{C}\left(1112^{\circ} \mathrm{F}\right)$, each maintained for $4 \mathrm{~h}$. The temperature was raised slowly until the required temperature was reached. The temperature was then maintained constant for $4 \mathrm{~h}$. The specimens were then removed out of the oven, cooled down to room temperature by keeping them at room temperature, and exposing them to air circulation by a fan, then they was weighed and coded. Figure 1 shows the specimens in the furnace.

Table 1. Plain SCC mix with constituent materials

\begin{tabular}{lllll} 
& Concrete mixture number & & \\
Materials & - & M0.05 & M0.10 & M0.15 \\
\hline Cement, $\mathrm{kg} / \mathrm{m}^{3}\left(\mathrm{Ib} / \mathrm{ft}^{3}\right)$ & $437.5(27.31)$ & $437.5(27.31)$ & $437.5(27.31)$ & $437.5(27.31)$ \\
Fly Ash, $\mathrm{kg} / \mathrm{m}^{3}\left(\mathrm{Ib} / \mathrm{ft}^{3}\right)$ & $120(7.49)$ & $120(7.49)$ & $120(7.49)$ & $120(7.49)$ \\
Coarse Aggregate, $\mathrm{kg} / \mathrm{m}^{3}\left(\mathrm{Ib} / \mathrm{ft}^{3}\right)$ & $730(45.57)$ & $730(45.57)$ & $730(45.57)$ & $730(45.57)$ \\
Fine Aggregate, $\mathrm{kg} / \mathrm{m}^{3}\left(\mathrm{Ib} / \mathrm{ft}^{3}\right)$ & $907(56.62)$ & $907(56.62)$ & $907(56.62)$ & $907(56.62)$ \\
Water, $\mathrm{kg} / \mathrm{m}^{3}\left(\mathrm{Ib} / \mathrm{ft}^{3}\right)$ & $178(11.11)$ & $178(11.11)$ & $178(11.11)$ & $178(11.11)$ \\
w/p $(\mathrm{ratio})$ & 0.32 & 0.32 & 0.32 & 0.32 \\
Superplasticizer, $\mathrm{kg} / \mathrm{m}^{3}\left(\mathrm{Ib} / \mathrm{ft}^{3}\right)$ & $8.1(0.506)$ & $8.1(0.506)$ & $8.1(0.506)$ & $8.1(0.506)$ \\
Polypropylene fibers, $\%$ by volume of mix & 0.0 & 0.05 & 0.10 & 0.15 \\
\hline
\end{tabular}

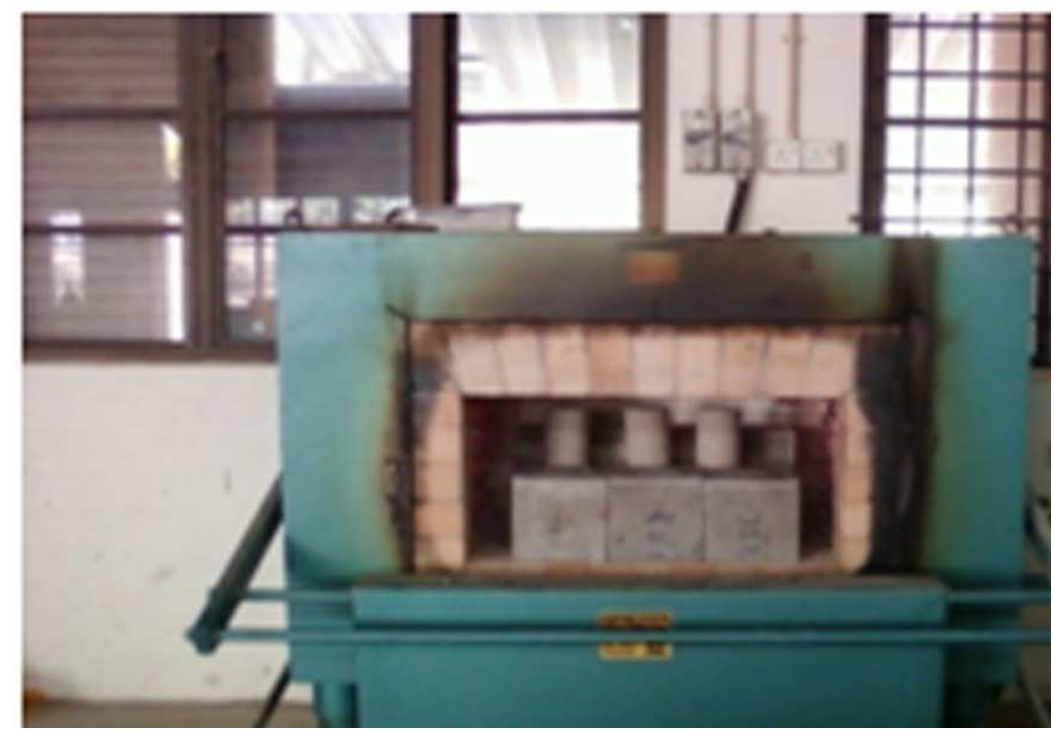

Fig. 1. The specimens in the furnace 


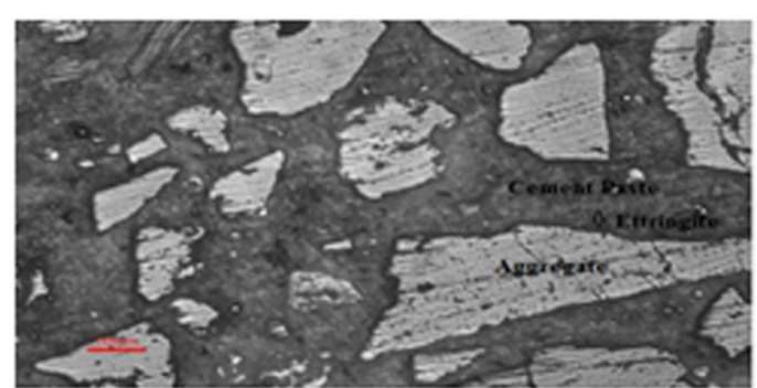

(a)

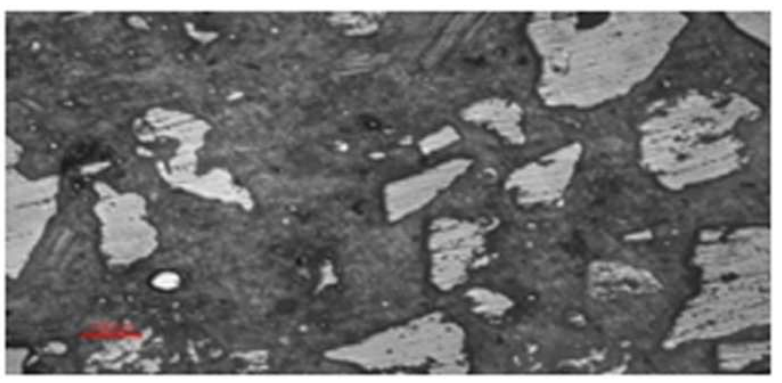

(c)

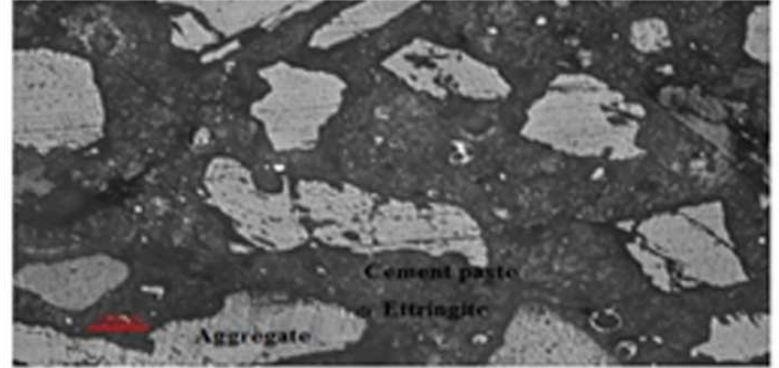

(b)

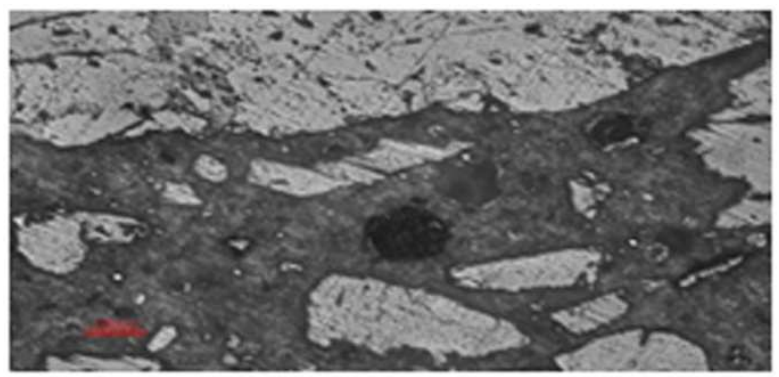

(d)

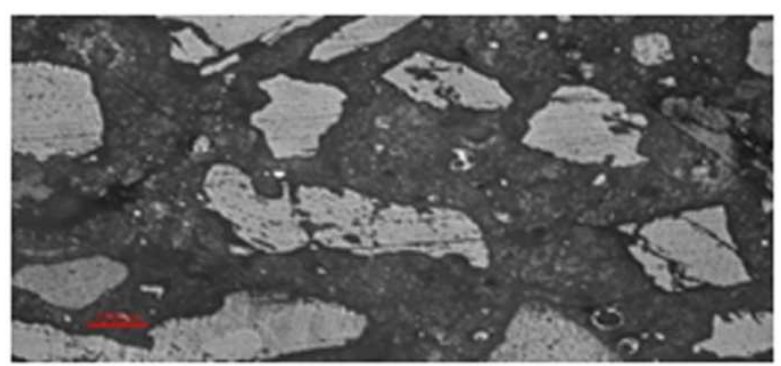

(e)

Fig. 2. Scanning electron microscopy of plain SCC from (a) to (e), (a) Plain SCC at Room Temperature (27 $\left.{ }^{\circ} \mathrm{C}\right)$, (b) Plain SCC at $600^{\circ} \mathrm{C}$, (c) Plain SCC at room temperature $\left(27^{\circ} \mathrm{C}\right)$, (d) $4 \mathrm{~h}, 400^{\circ} \mathrm{C}$ and plain SCC, (e) $4 \mathrm{~h}, 600^{\circ} \mathrm{C}$ and plain SCC

The specimens are broken at 90 days to permit an evaluation of the mix. The real dimensions of the test specimens and the maximum applied load were measured.

The micro structure of SCC mixtures was tested on a small specimen of concrete with a diameter of approximately $25 \mathrm{~mm}$ (1 inch) and a thickness of about 4 $\mathrm{mm}(0.16 \mathrm{inch})$, and the specimen had been cut in order to be tested by SEM. The specimens were previously coated with a very thin layer of gold to prevent charge built-up on the surface after being subjected to elevated temperature (Fig. 2).

\section{Results and Discussion}

\section{Spalling Assessment}

Figure 3 shows specimens subjected to fire test. In Fig. 3a, no spalling occurs although there were specimens of plain SCC, but there were small cracks on the surface of the specimens when the temperature was $200^{\circ} \mathrm{C}\left(392^{\circ} \mathrm{F}\right)$ for a heating period of $2 \mathrm{~h}$.
Also in Fig. 3b, specimens of plain SCC showed more cracks appeared on the surface when the time of exposure was increased to $4 \mathrm{~h}$. In Fig. 3c, plain SCC specimens showed small cracks appear and no explosive spalling occurred with peak temperature maintained at $400^{\circ} \mathrm{C}\left(752^{\circ} \mathrm{F}\right)$ for $4 \mathrm{~h}$.

Figure 4 shows some of the specimens after heating with peak temperature maintained at $600^{\circ} \mathrm{C}$ $\left(1112^{\circ} \mathrm{F}\right)$ for 2 and $4 \mathrm{~h}$. In Fig. $4 \mathrm{a}$, the most common type of damage was in specimen number 2, as nearly everything from the middle to the upper of the specimens were exploded; in specimen number 3, explosive spalling took place in the upper part as one big piece; and specimen number 1 did not spall. In other modes, Fig. $4 \mathrm{~b}$ nearly behaved in the same way and showed the same trend because they were tested under the same temperature, which was $600^{\circ} \mathrm{C}$ $\left(1112^{\circ} \mathrm{F}\right)$. All these tests were conducted on plain SCC specimens at $600^{\circ} \mathrm{C}\left(1112^{\circ} \mathrm{F}\right)$ with an exposure time of 2 and $4 \mathrm{~h}$. 


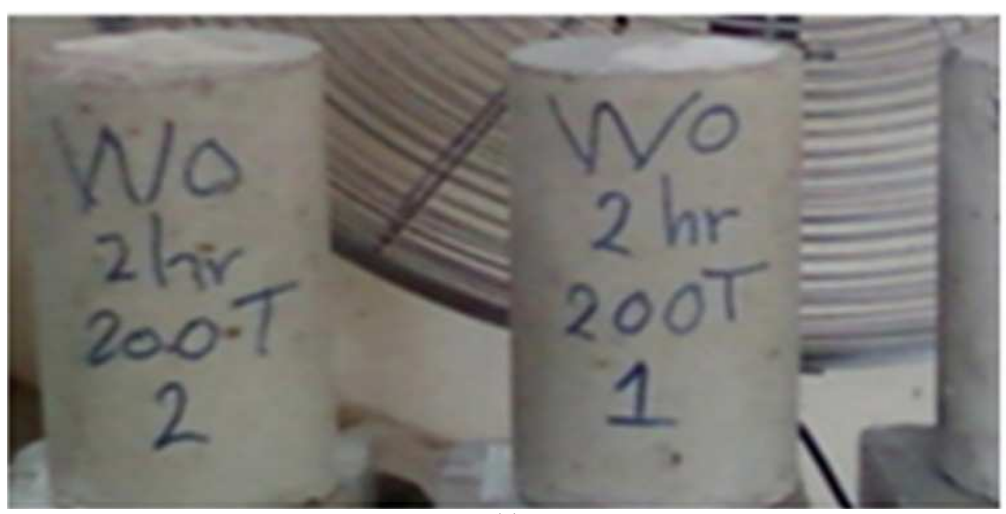

(a)

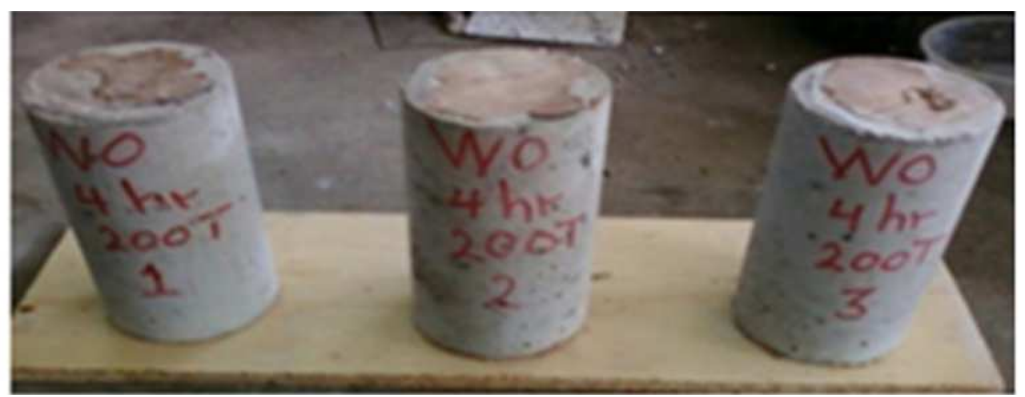

(b)

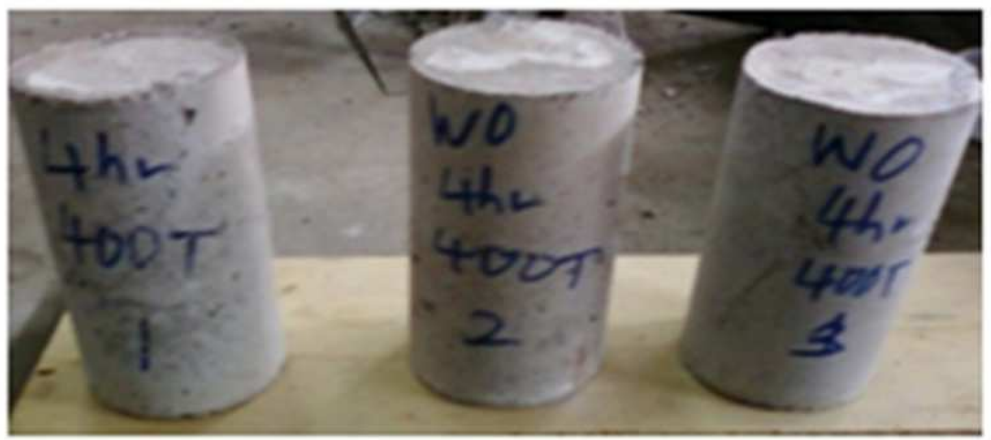

(b)

Fig. 3. Plain SCC mixtures specimens, (a) $2 \mathrm{~h}, 200^{\circ} \mathrm{C}$ and plain SCC, no explosive spalling, (b) $4 \mathrm{~h}, 200^{\circ} \mathrm{C}$ and plain $\mathrm{SCC}$, no explosive spalling, (c) $4 \mathrm{~h}, 400^{\circ} \mathrm{C}$ and plain SCC, no explosive spalling

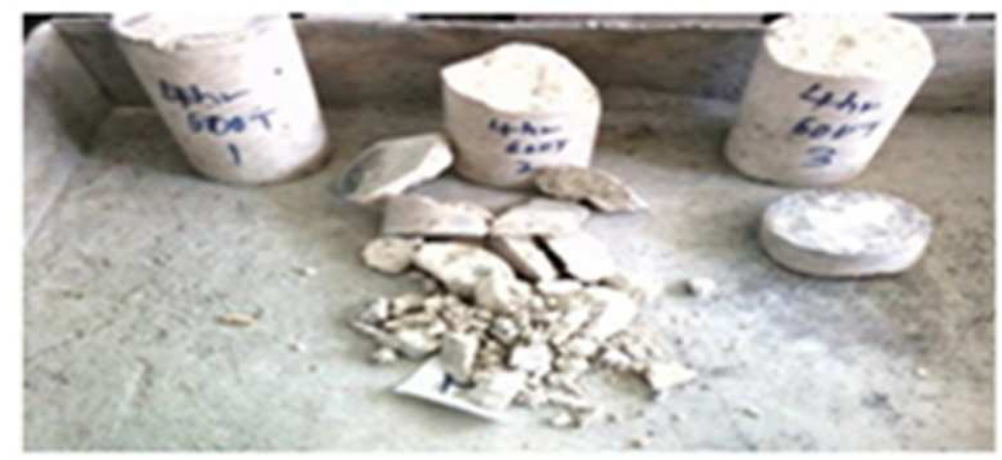

(a) 


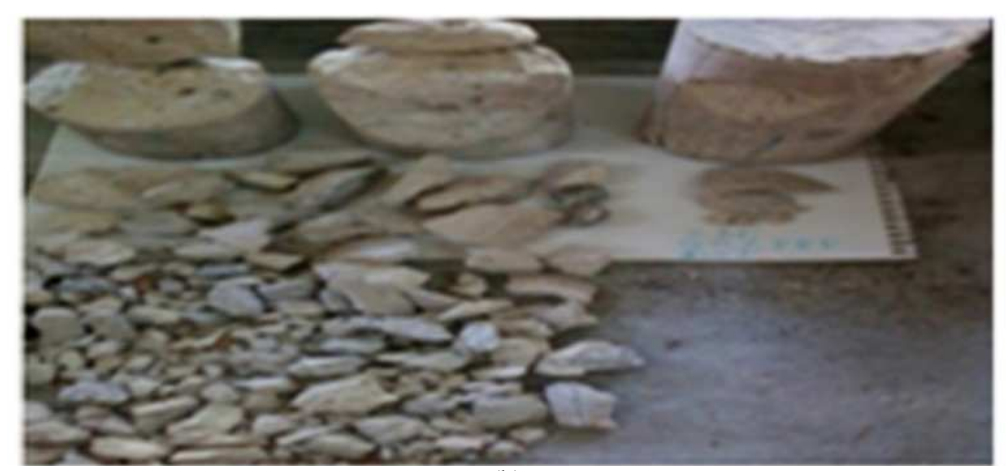

(b)

Fig. 4. Plain SCC Mixtures with Explosive Spalling Clear, (a) $4 \mathrm{~h}, 600^{\circ} \mathrm{C}$, plain SCC explosive spalling clear, (b) $2 \mathrm{~h}, 600^{\circ} \mathrm{C}$, plain SCC, explosive spalling clear

A compression with degree of gradation was done by Equation 1 (Da Silva and de Brito, 2015) to identify the criterion used to quantify the spalling severity:

Spalling degree $=\frac{m_{1}}{m_{2}}$

Where:

$m_{1}=$ Mass of concrete lost due to spalling

$m_{2}=$ Mass of the specimen before testing

If the spalling degree $=0.3$, then $30 \%$ of the specimen mass was lost as a direct result of spalling. For the test on specimens with plain SCC and a $2 \mathrm{~h}$ exposure time and at $600^{\circ} \mathrm{C}\left(1112^{\circ} \mathrm{F}\right)$, the spalling was measured as in Equation 1 as follows:

$$
\text { Spalling degree }=\frac{0.24}{1.58}=0.15
$$

This means that $15 \%$ of the cylinder specimens are lost as a direct result of spalling. Also, for a test on cylinder specimen at plain SCC fibers over a $4 \mathrm{~h}$ exposure time and at $600^{\circ} \mathrm{C}\left(1112^{\circ} \mathrm{F}\right)$, the spalling is measured as follows:

$$
\text { Spalling degree }=\frac{0.5}{1.6}=0.31
$$

This means that $31 \%$ of the cylinder specimens are lost as a direct result of spalling.

\section{Scanning Electron Microscopy of Different Percentages of Polypropylene Fibers}

Figure 5a-h show the matrix SCC with PP fibers and granite aggregate adherence determined under scanning through electronic microscope for $0.0,0.05,0.10$ and $0.15 \%$ of PP fibers by volume of SCC mixture.

The permeability and mineralogy of the aggregate may influence concrete when exposed to fire.
Depending on the rate of heating, permeability, size and condition of the aggregate, the porous aggregate may be susceptible to disruptive expansion. Granite, which is formed from siliceous aggregate containing quartz, can distress in concrete at a temperature of $500^{\circ} \mathrm{C}\left(932^{\circ} \mathrm{F}\right)$ to $700^{\circ} \mathrm{C}\left(1292^{\circ} \mathrm{F}\right)$. The loss is due to decomposition of calcium hydroxide in the cement paste as well as the decomposition of calcium silicate hydrate compound (C-S-H) phases. This is followed by the formation of $\beta-C 2 S$ (Schneider et al., 1982). The mineralogy of aggregate determines the differential thermal expansions between the cement paste, the aggregate and the ultimate strength of the interfacial transition zone.

The temperature effect on hydrated cement paste depends on the degree of hydration and the moisture state. It consists mainly of calcium sulphoaluminate hydrates, calcium silicate hydrate, and calcium hydroxide. A saturated paste contains great amounts of capillary and adsorbed water, so that when the temperature rises the water will vaporize to steam. The temperature of the concrete will not rise until all the evaporable water has been removed. SCC contains constituent materials with a small size that makes the cement paste impermeable such that it can conserve the water inside. With an increasing rate of temperature, damage may take place in the form of explosive spalling. This occurs when the vapor pressure of the steam inside the cement paste increases at a rate greater than the tensile strength of the cement paste.

Figure $5 \mathrm{a}$ to $\mathrm{h}$ indicates that at 2 and $4 \mathrm{~h}$ exposure times and with the increase in temperature to $200^{\circ} \mathrm{C}$ $\left(392^{\circ} \mathrm{F}\right), 400^{\circ} \mathrm{C}\left(752^{\circ} \mathrm{F}\right), 600^{\circ} \mathrm{C}\left(1112^{\circ} \mathrm{F}\right)$ and at $200^{\circ} \mathrm{C}$ $\left(392^{\circ} \mathrm{F}\right)$ to $300^{\circ} \mathrm{C}\left(572^{\circ} \mathrm{F}\right)$, the interlayer C-S-H water and some of the chemically combined water from the C$\mathrm{S}-\mathrm{H}$ and sulphoaluminate hydrates would also be lost. In addition, further dehydration of the cement paste due to decomposition of calcium hydroxide begins at about $500^{\circ} \mathrm{C}\left(932^{\circ} \mathrm{F}\right)$ to $600^{\circ} \mathrm{C}\left(1112^{\circ} \mathrm{F}\right)$. 


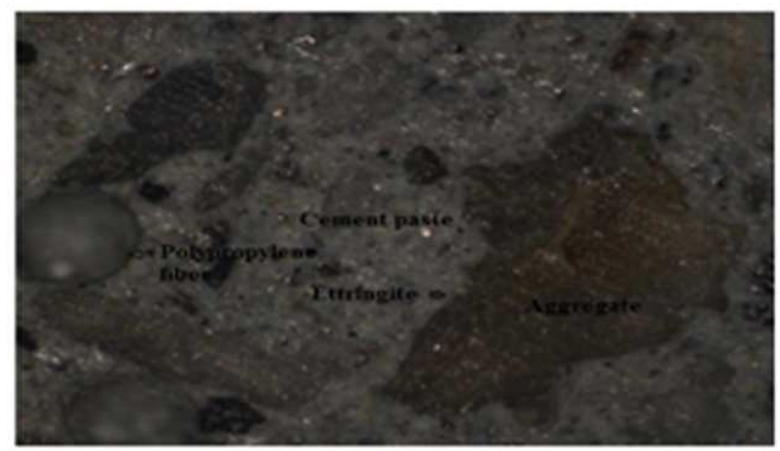

(a)

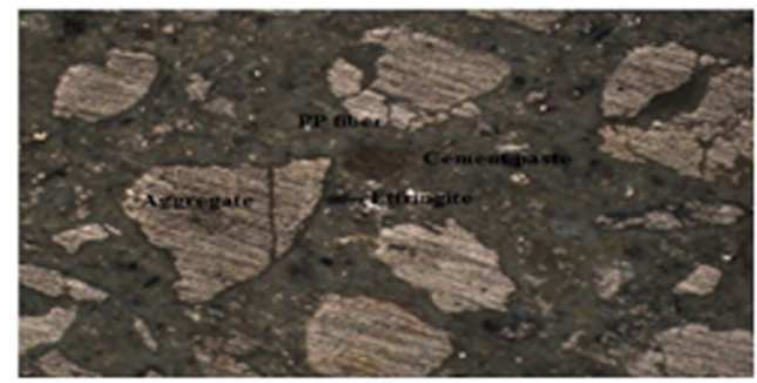

(c)

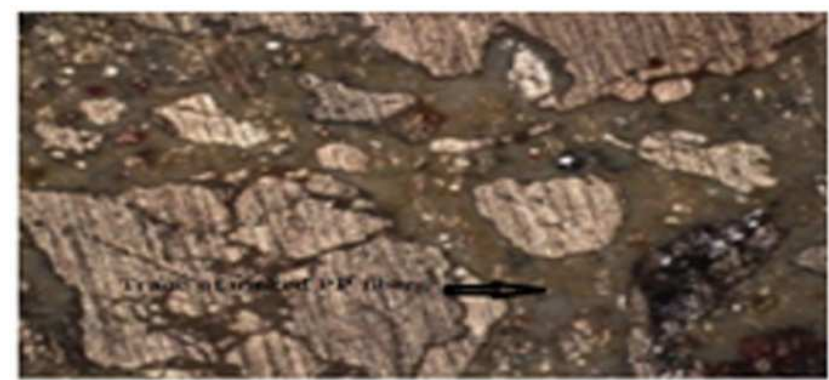

(e)

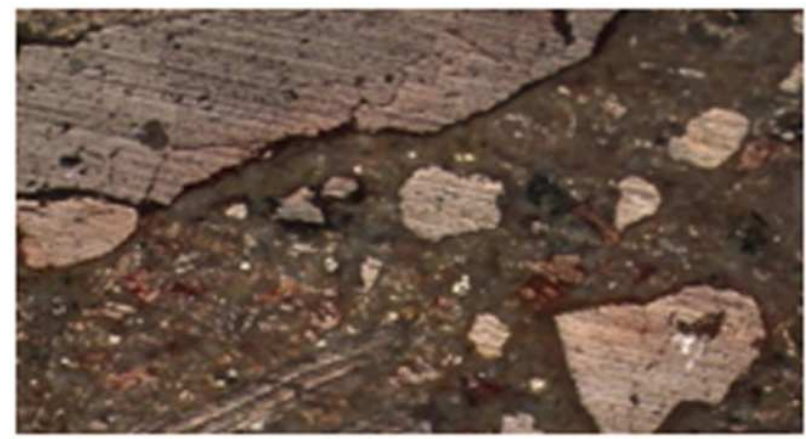

(g)

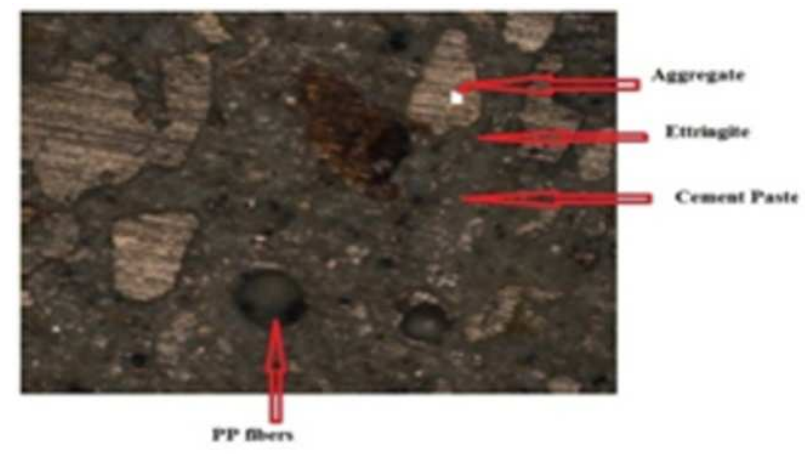

(b)

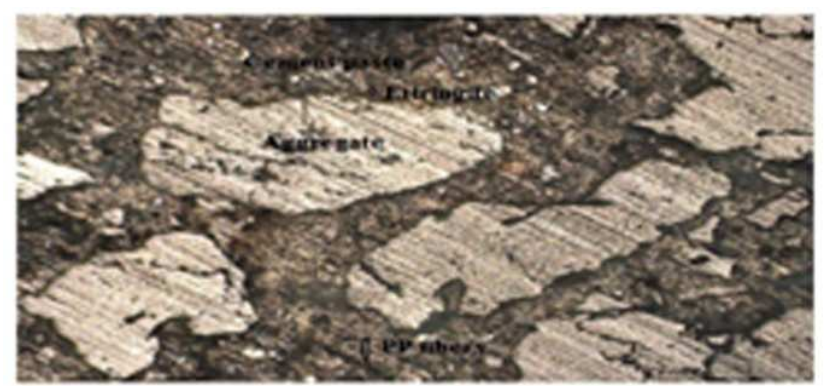

(d)

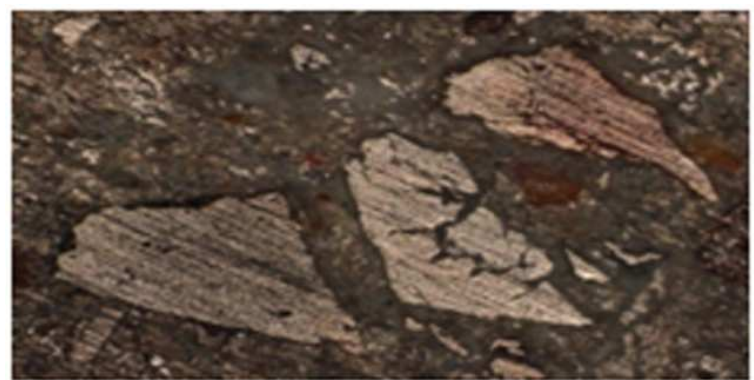

(f)

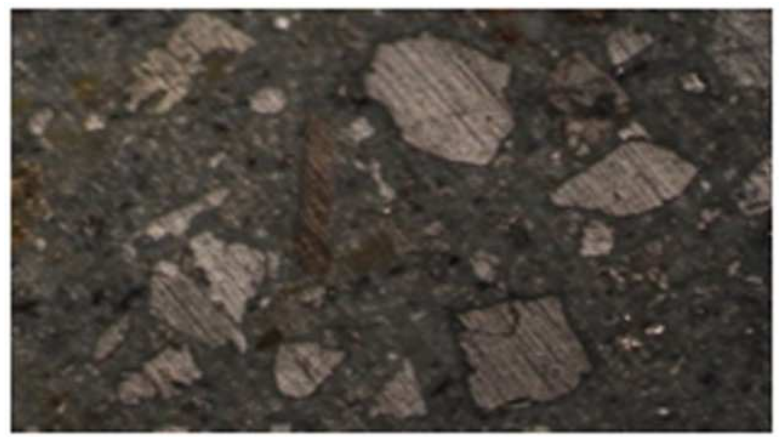

(h)

Fig. 5. Scanning Electron Microscopy of SCC from (a) to (h), (a) $2 \mathrm{~h}, 200^{\circ} \mathrm{C}$ and $0.10 \% \mathrm{PP}$, (b) $2 \mathrm{~h}, 200^{\circ} \mathrm{C}$ and $0.15 \% \mathrm{PP}$, (c) $2 \mathrm{~h}$, $400^{\circ} \mathrm{C}$ and $0.05 \% \mathrm{PP}$, (d) $2 \mathrm{~h}, 400^{\circ} \mathrm{C}$ and $0.10 \% \mathrm{PP}$, (e) $2 \mathrm{~h}, 600^{\circ} \mathrm{C}, 0.05 \% \mathrm{PP}$, (f) $2 \mathrm{~h}, 400^{\circ} \mathrm{C}$ and $0.15 \% \mathrm{PP},(\mathrm{g}) 2 \mathrm{~h}, 600^{\circ} \mathrm{C}$ and $0.15 \% \mathrm{PP}$, (h) $4 \mathrm{~h}, 200^{\circ} \mathrm{C}$ and $0.05 \% \mathrm{PP}$ 


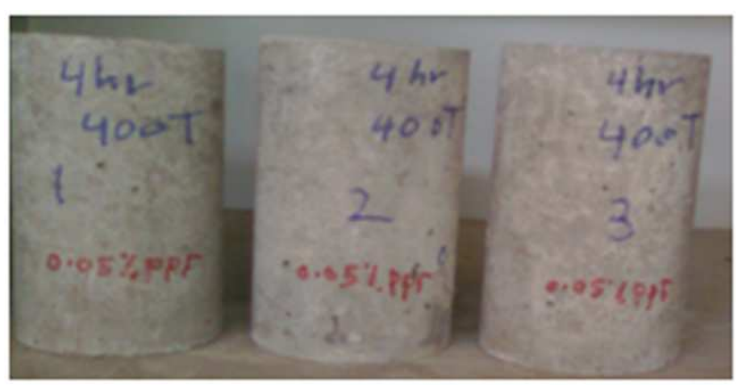

(a)

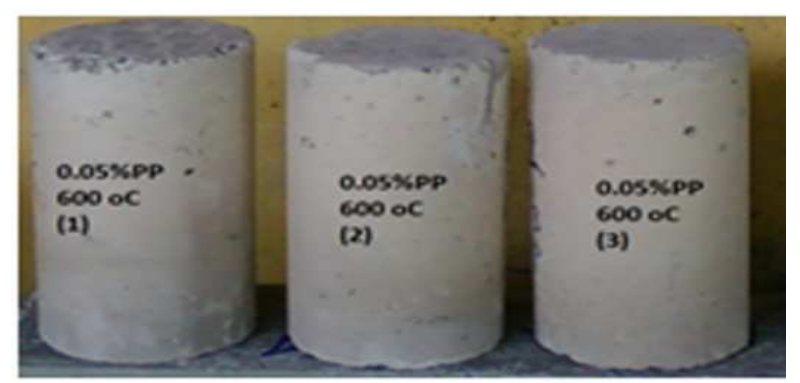

(b)

Fig. 6. SCC with addition of PP fibers no spalling clear (a) $0.05 \%$ PP fibers, $4 \mathrm{~h}$ and $400^{\circ} \mathrm{C}$, (b) $0.05 \%$ PP fibers, $4 \mathrm{~h}$ and $600^{\circ} \mathrm{C}$

\section{Spalling Assessment of Percentages of Polypropylene}

Figure $6 \mathrm{a}$ and $\mathrm{b}$ shows that addition of PP fibers could be used to mitigate spalling. As seen in Fig. 6a, the SCC with $0.05 \%$ of PP fibers with peak temperature maintained at $400^{\circ} \mathrm{C}\left(752^{\circ} \mathrm{F}\right)$ for $4 \mathrm{~h}$ no spalling occurred. Furthermore, in Fig. $6 \mathrm{~b}$, as the peak temperature was maintained at $600^{\circ} \mathrm{C}\left(1112^{\circ} \mathrm{F}\right)$ for $4 \mathrm{~h}$ time of exposure, no explosive spalling occurred.

\section{Scanning Electron Microscopy General Assessment}

In general, it is concluded that a study using SEM was completed to reveal the reaction of the SCC to heated temperatures. Images of the $\mathrm{SCC}$ exposed to lower temperatures of $70^{\circ} \mathrm{C}\left(158^{\circ} \mathrm{F}\right)$ show that ettringite occurred. The loss of free water takes place at temperatures greater than $105^{\circ} \mathrm{C}\left(221^{\circ} \mathrm{F}\right)$. The PP melts at $162^{\circ} \mathrm{C}\left(323.6^{\circ} \mathrm{F}\right)$ and also vaporizes as the temperature and exposure time increases. When the test cylinders cool down for testing, the melted PP fibers become hardened and brittle, as they are allowed to remain in the cylinders to give them strength. Oxidation of the iron oxide in the aggregate occurs at about $300^{\circ} \mathrm{C}$ $\left(752^{\circ} \mathrm{F}\right)$ and the dissociation of the sand particles in parts of the siliceous aggregate can be observed in the images. The dissociation of Portland-ite at $400^{\circ} \mathrm{C}$ $\left(752^{\circ} \mathrm{F}\right)$ to $600^{\circ} \mathrm{C}\left(1112^{\circ} \mathrm{F}\right)$ can also be seen. At $600^{\circ} \mathrm{C}$ $\left(1112^{\circ} \mathrm{F}\right)$ more PP fibers vaporize, leaving less liquid available in the molds and so the samples exhibit less strength at higher temperatures.

Also, changes were noted in the volume associated with the water held by the small pores and the melting of the PP fibers at $162^{\circ} \mathrm{C}\left(323.6^{\circ} \mathrm{F}\right)$ with respect to the water vapor that comes from capillary water with voids larger than $0.05 \mu \mathrm{m}$ and from absorbed water that is held close to the solid surface of hydrated cement paste by attractive forces. Water is integrated into the $\mathrm{C}-\mathrm{S}-\mathrm{H}$ structure and also there is water in the microstructure. When these all evaporate, the volume of the voids will increase as the testing temperature increases from $27^{\circ} \mathrm{C}$ $\left(80.6^{\circ} \mathrm{F}\right), 200^{\circ} \mathrm{C}\left(392^{\circ} \mathrm{F}\right), 400^{\circ} \mathrm{C}\left(752^{\circ} \mathrm{F}\right)$, to $600^{\circ} \mathrm{C}$ $\left(1112^{\circ} \mathrm{F}\right)$. The melting and releasing of PP fibers to the surface of the sample can be seen in the images as they form channelization for the water vapor to flow outside the sample. This phenomenon mitigates explosive spalling that can occur in high performance concrete, of which SCC is an example.

\section{Conclusion}

The following conclusions can be derived from the investigation on the behavior of SCC at elevated temperature.

SEM can reveal the reaction of the samples when heated. Images of samples.

Exposure to low temperatures below $70^{\circ} \mathrm{C}\left(158^{\circ} \mathrm{F}\right)$ show that ettringite occurs. The loss of free water takes place at temperatures greater than $105^{\circ} \mathrm{C}\left(221^{\circ} \mathrm{F}\right)$. The PP melts at $162^{\circ} \mathrm{C} 1$ testing, the melted PP fibers become hardened and brittle, allowed to remain in the cylinders to give them strength. Oxidation of the ironoxidein the aggregate and the dissociation of the sand particles in parts of siliceous aggregateoccur at about $300^{\circ} \mathrm{C}$. Also, the dissociation of portlandite at $400^{\circ} \mathrm{C}\left(752^{\circ} \mathrm{F}\right)$ to $600^{\circ} \mathrm{C}\left(1112^{\circ} \mathrm{F}\right)$ is visible, while at $600^{\circ} \mathrm{C}\left(1112^{\circ} \mathrm{F}\right)$ more $\mathrm{PP}$ fibers vaporize, leaving less liquid available in molds and so the samples exhibit less strength at higher temperatures.

The changes in volume associated with water held by small pores and the melting of PP fibers at $162^{\circ} \mathrm{C}$ $\left(323.6^{\circ} \mathrm{F}\right)$ with respect to the water vapor that comes from capillary water with voids larger than $0.05 \mu \mathrm{m}$ and from absorbed water that is closed to the solid surface of hydrated cement paste by attractive forces; water integrated of C-S-H structure and water in the microstructure-these all evaporate, then the voids will increase as testing temperature increases from $27^{\circ} \mathrm{C}$ $\left(80.6^{\circ} \mathrm{F}\right), 200^{\circ} \mathrm{C}\left(392^{\circ} \mathrm{F}\right), 400^{\circ} \mathrm{C}\left(752^{\circ} \mathrm{F}\right)$ and $600^{\circ} \mathrm{C}$ $\left(1112^{\circ} \mathrm{F}\right)$. The melting and releasing of PP fibers to the surface of the sample was seen in the images to form channelization for water vapor to flow outside the sample. This phenomenon mitigates explosive spalling that occurs in high performance concrete and SCC is one of them as seen from the images of the microscopy tests. 


\section{Acknowledgement}

Authors would like to acknowledge Universiti Tenaga Nasional, Malaysia, and Al-Hussein Bin Talal University, Jordan, for facilitating their laboratories for completing this research.

\section{Author's Contributions}

Mahmoud B. Alhasanat and Arabi N. Al Qadi: Participated in all experiments, coordicated the dataanalysis and contributed to the writing of the manuscript.

Omar A. Al Khashman and Ahmad Dahamsheh: Particapted in all experiments, coordinated the dataanalysis.

\section{Ethics}

This article is original and contains unpublished material. The corresponding author confirms that all of the other authors have read and approved the manuscript and no ethical issues involved.

\section{References}

Al-Mutairi, N.M. and M.S. Al-Shaleh, 1997. Assessment of fire-damaged Kuwaiti structures. J. Mater. Civil Eng., 9: 7-14. DOI: 10.1061/(ASCE)0899-1561(1997)9:1(7)

Crook, D.N. and M.J. Murray, 1970. Regain of strength after firing of concrete. Magaz. Concrete Res., 22: 149-154. DOI: 10.1680/macr.1970.22.72.149

Da Silva, P.R. and J. de Brito, 2015. Experimental study of the porosity and microstructure of SelfCompacting Concrete (SCC) with binary and ternary mixes of fly ash and limestone filler. Constr. Build. Mater., 86: 101-112.

DOI: 10.1016/j.conbuildmat.2015.03.110

Jahren, P.A., 1989. Fire resistance of high strength/dense concrete with particular references to the use of condensed silica fume-a review. Proceedings of the 3rd International Conference, Fly Ash, Silica Fume, Slag and Natural Pozzolans in Concrete, (NPC' 89), Detroit, USA, pp: 1013-1049.
Kanéma, M., P. Pliya, A. Noumowé and J.L. Gallias, 2011. Spalling, thermal and hydrous behavior of ordinary and high-strength concrete subjected to elevated temperature. J. Mater. Civil Eng., 23: 921-930. DOI: 10.1061/(ASCE)MT.1943-5533.0000272

Lea, F.C., 1920. The effect of temperature on some of the properties of materials. Engineering, 110: 293-298.

Mehta, P.K. and P.J.M. Monteiro, 1993. Concrete: Structure, Properties and Materials. 2nd Edn., Prentice-Hall, Englewood Cliffs, ISBN-10: 0131756214, pp: 548.

Metey, S.M. and V.P. Veiko, 1998. Laser-Assisted Microtechnology, 2nd Edn., R.M. Springer, Berlin, ISBN-10: 354063973X, pp: 270.

Nazari, A. and S. Riahi, 2010. Microstructural, thermal, physical and mechanical behavior of the self compacting concrete containing $\mathrm{SiO}_{2}$ nanoparticles. Mater. Sci. Eng.: A, 527: 7663-7672. DOI: $10.1016 /$ j.msea.2010.08.095

Neves, I.C., F.A. Branco and J.C. Valente, 1997. Effects of formwork fires in bridge construction. Concrete Int., 19: 41-46.

Noumowē, A., H. Carre, A. Daoud and H. Toutanji, 2006. High-strength self-compacting concrete Exposed to fire test. J. Mater. Civil Eng., 18: 754-758. DOI: 10.1061/(ASCE)0899-1561(2006)18:6(754)

Peng, G.F. and Z.S. Huang, 2008. Change in microstructure of hardened cement paste subjected to elevated temperatures. Constr. Build. Mater., 22: 593-599. DOI: 10.1016/j.conbuildmat.2006.11.002

Schneider, U., U. Diederichs and C. Ehm, 1982. Effect of temperature on steel and concrete for PCRV's. Nucl. Engng. Des., 67: 245-258. DOI: 10.1016/0029-5493(82)90144-3 